\title{
AUSENCIA Y MOVILIDAD
}

ANA LUCÍA ROJAS

Universidad Autónoma de Morelos, México anarojas.arte@gmail.com

A usencia, movilidad y metáfora son las constantes que convergen en mi trabajo. Con ellas describo - a través de los procesos de la gráfica-, una serie de posibilidades en donde el individuo está ausente de un discurso filosófico, un lugar o una metáfora.

En mi proceso recopilo y transformo fotografías de mi autoría para describir fenómenos migratorios que devienen en matrices de grabado. Con ellas conformo un archivo de tipos móviles/símbolos personales con los que escribo ensayos visuales: proyectos que tienen una premisa, un desarrollo y un fin específico, que puede o no ser comprobable a través del lenguaje del arte. En ellos, los elementos figurativos se entremezclan con los símbolos abstractos, las siluetas que velan la presencia humana se repiten en composiciones con paisajes que describen travesías del migrante.

El aspecto formal de mi obra se caracteriza por el uso experimental de la placa de grabado -ya sea de relieve o hueco-y el uso alternado de diversos soportes de papel o textil. En pocas ocasiones hago una edición numerada ya que pondero los procesos de repetición aleatorios en los que conceptualizo el uso de la técnica, al utilizar la matriz de manera simbólica y repetitiva una sobre otra en múltiples movimientos. Construyo imágenes a través de capas de tinta en donde las temporalidades son perceptibles mediante la yuxtaposición de elementos: un elemento impreso sobre otro, fue forzosamente impreso después de aquel que se encuentra al fondo. La temporalidad es físicamente representable en el arte de la impresión. Todos estos elementos conforman diversas narrativas en torno a la movilidad desde pequeñas migraciones locales hasta fenómenos fuera de nuestra frontera. 


\section{ACUMULACIÓN}

Acumulación 1 y 2 y Acumulaciones 1 y 2. Xilografía y linóleo, cuatro piezas de 100 x 70cm, 2017-2018.
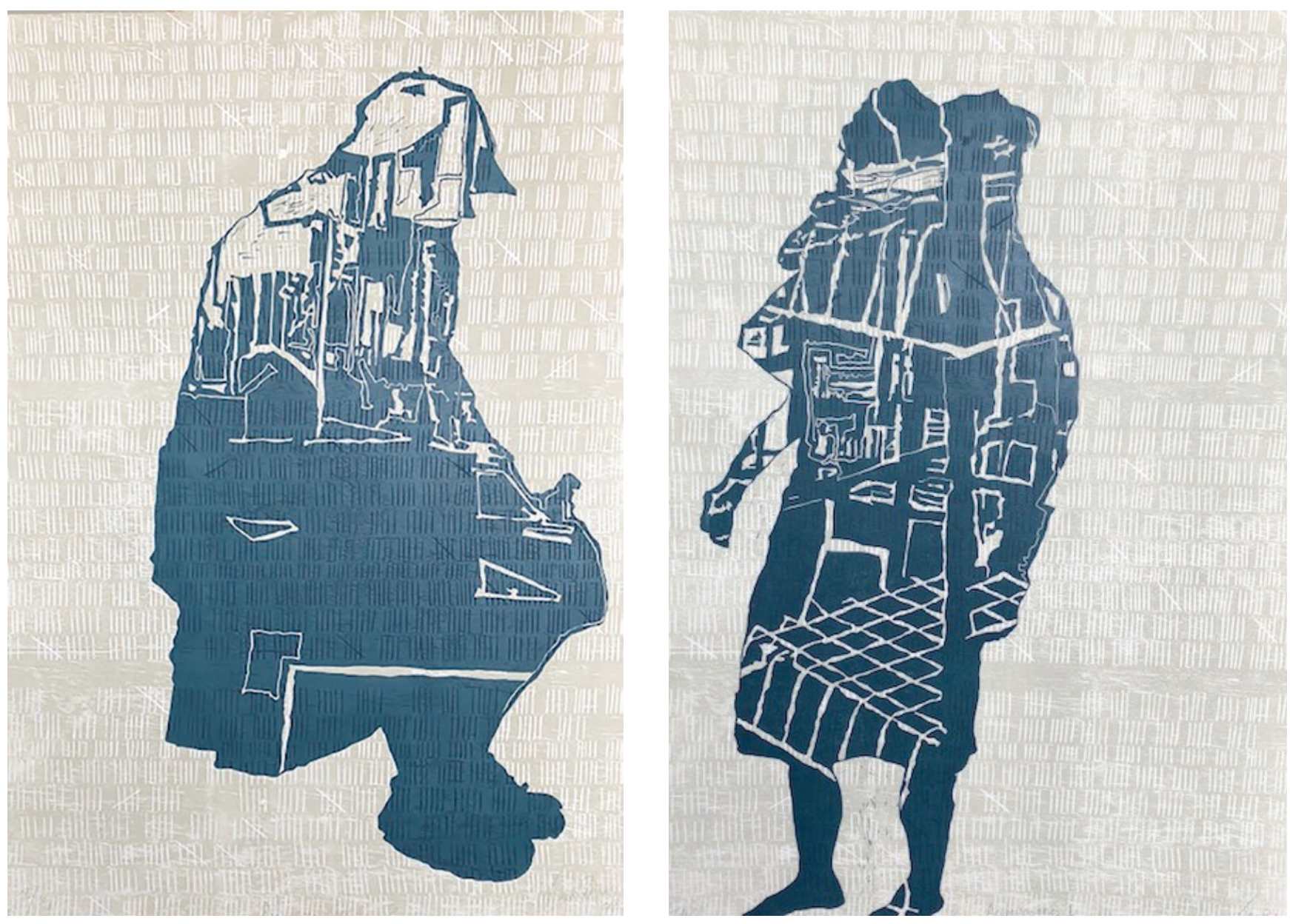

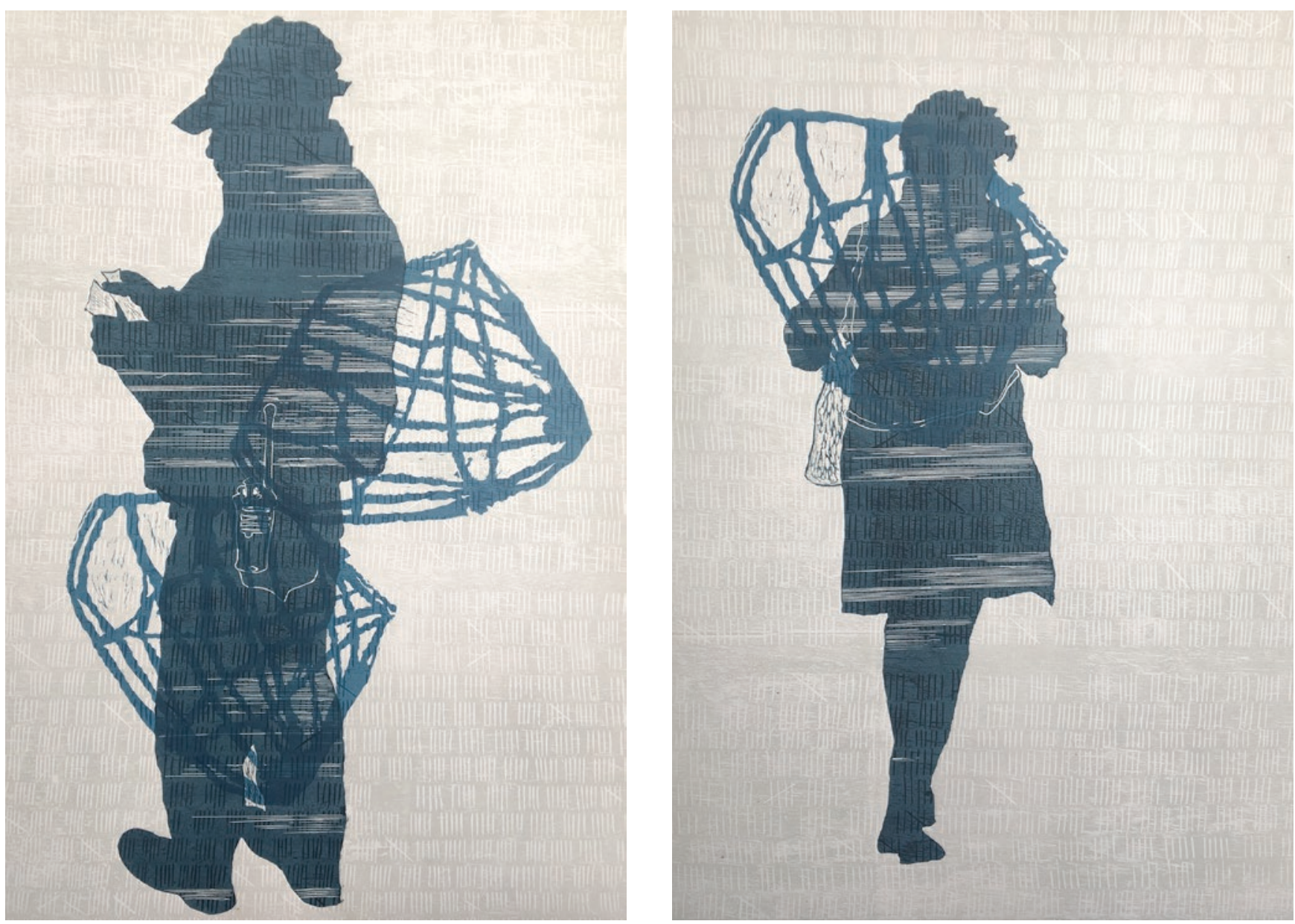


\section{TRANSFIGURACIÓN}

Transfiguración I, II, III y IV. Xilografía y linóleo sobre textil y tepalcates bordados, 150 x 600 cm, 2020-2021.

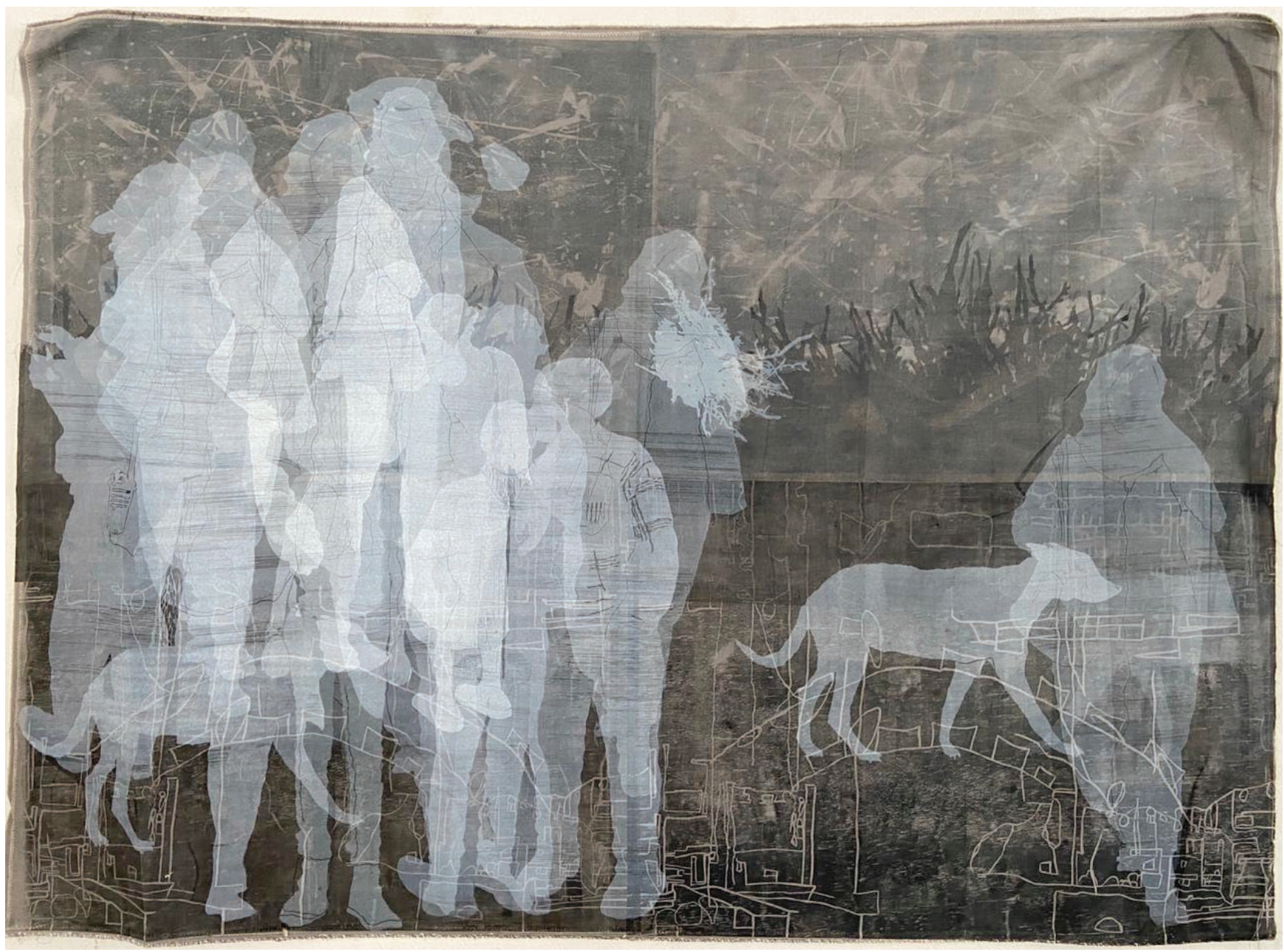




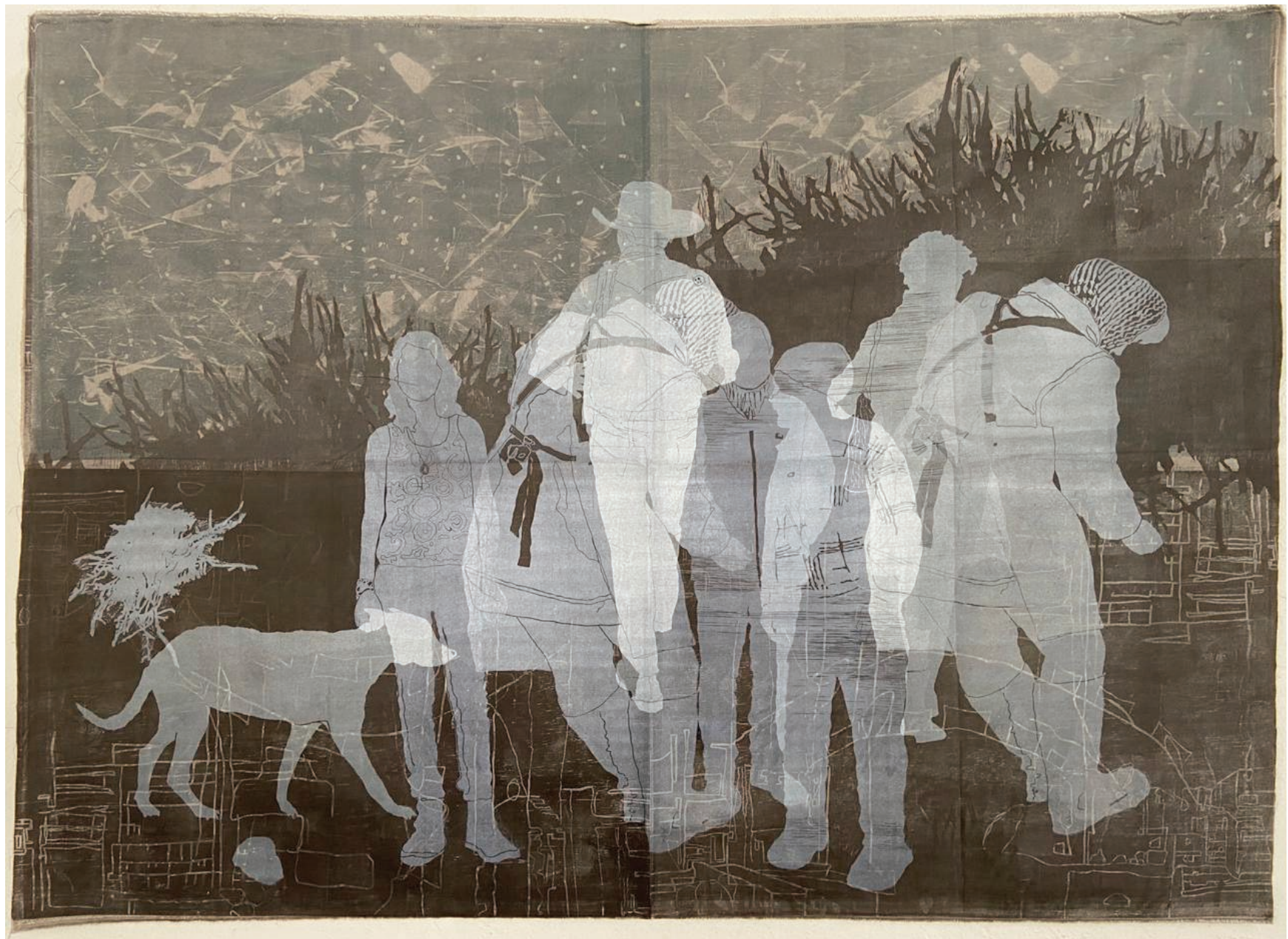




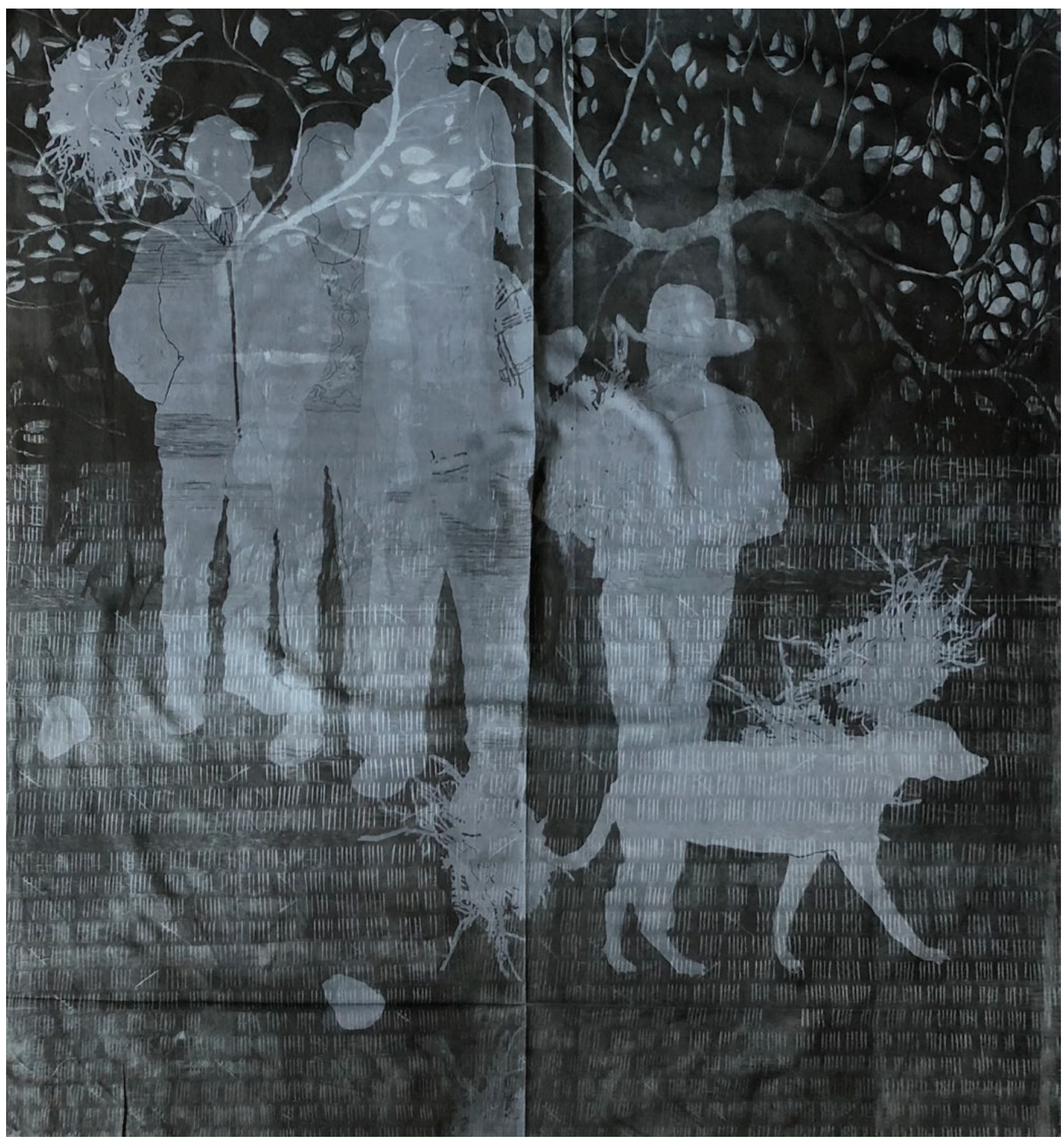




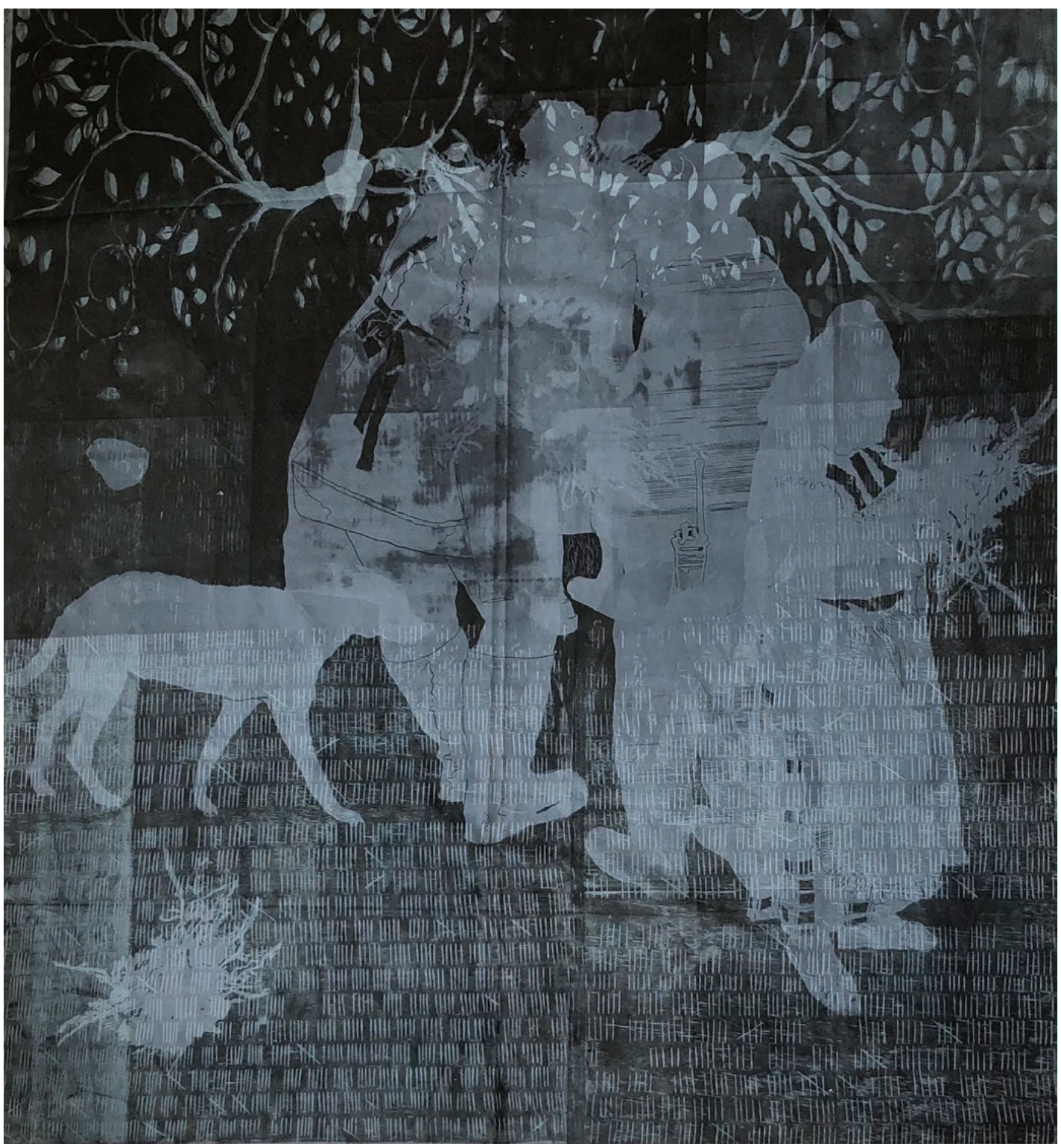




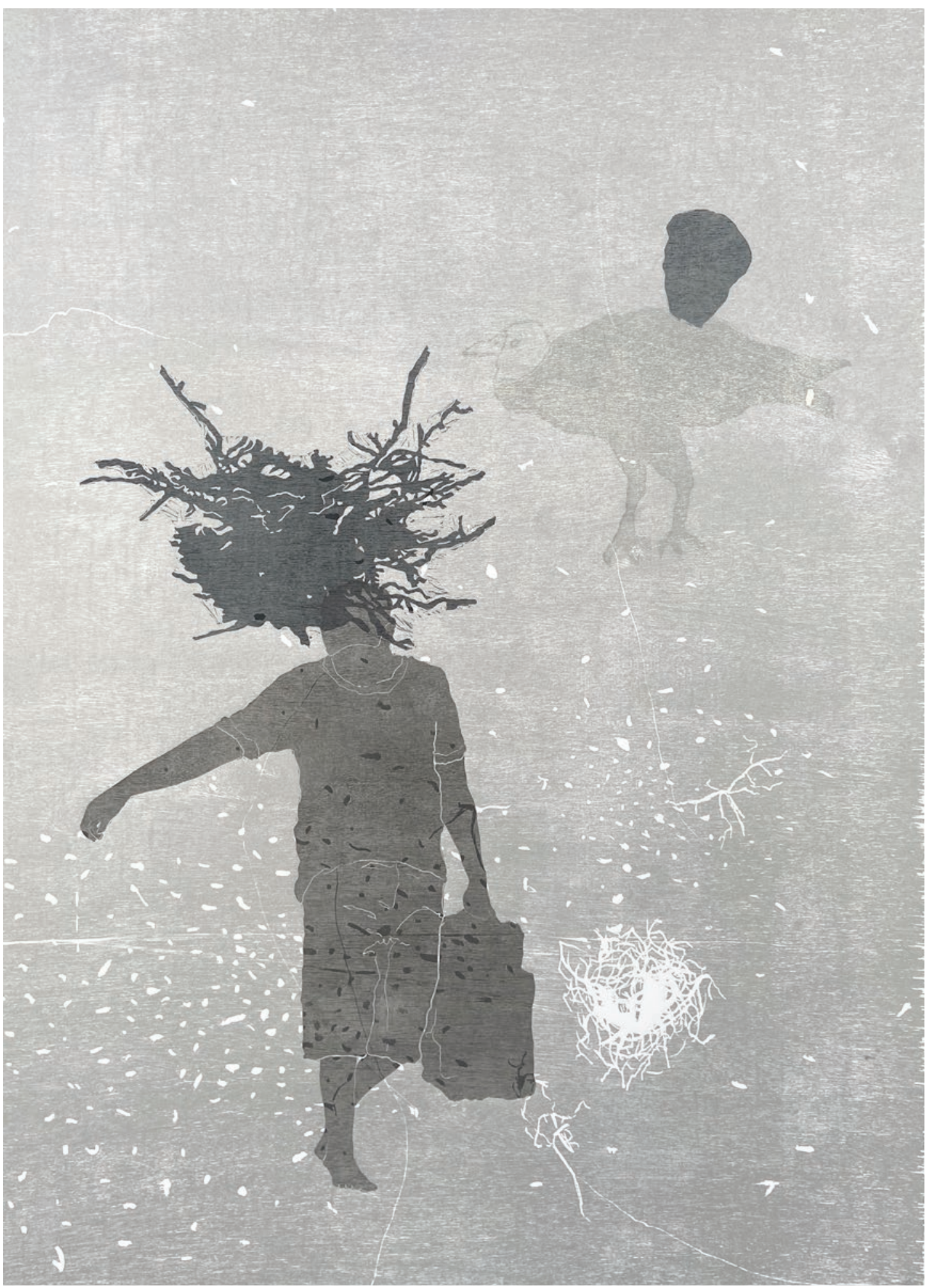




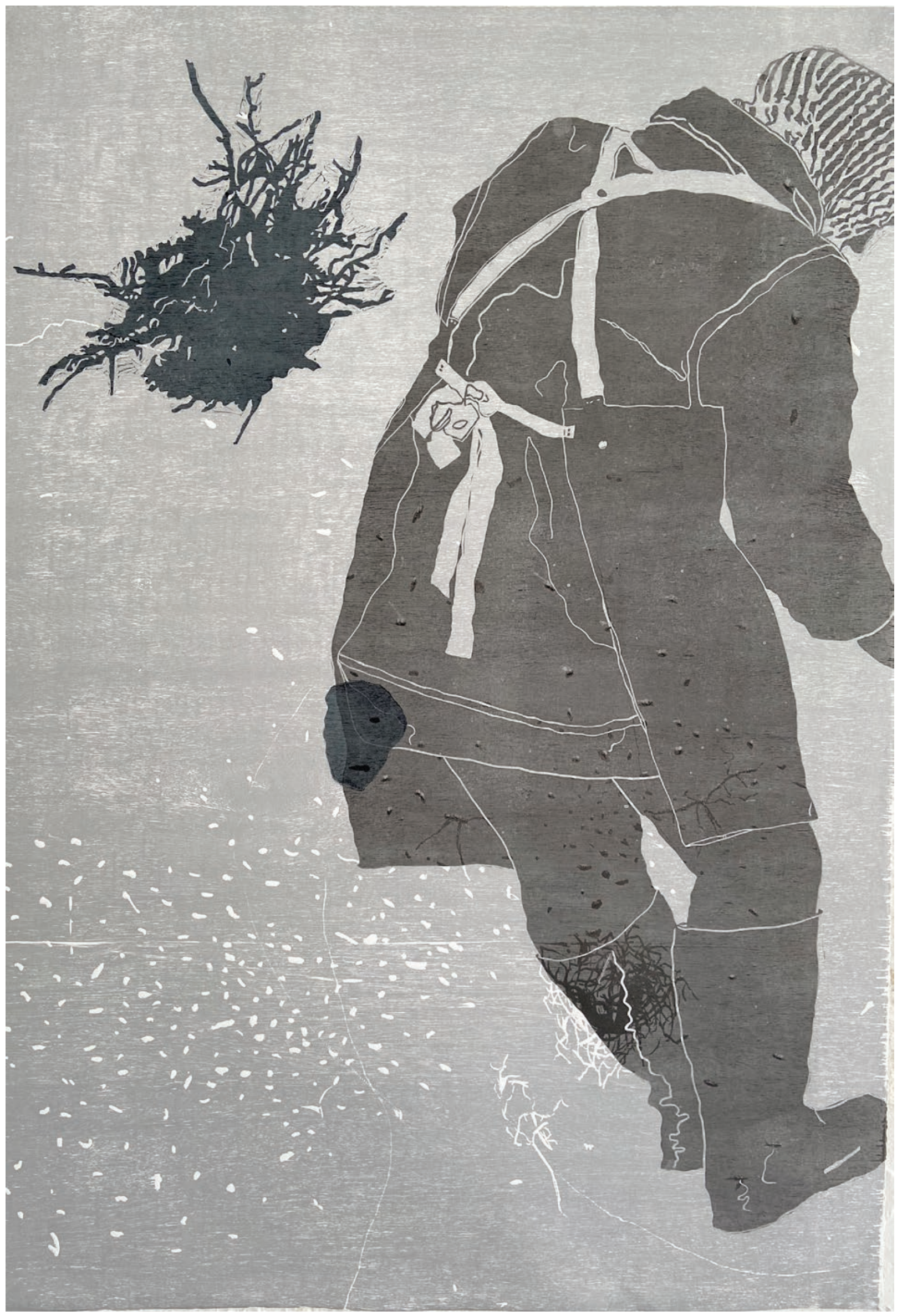




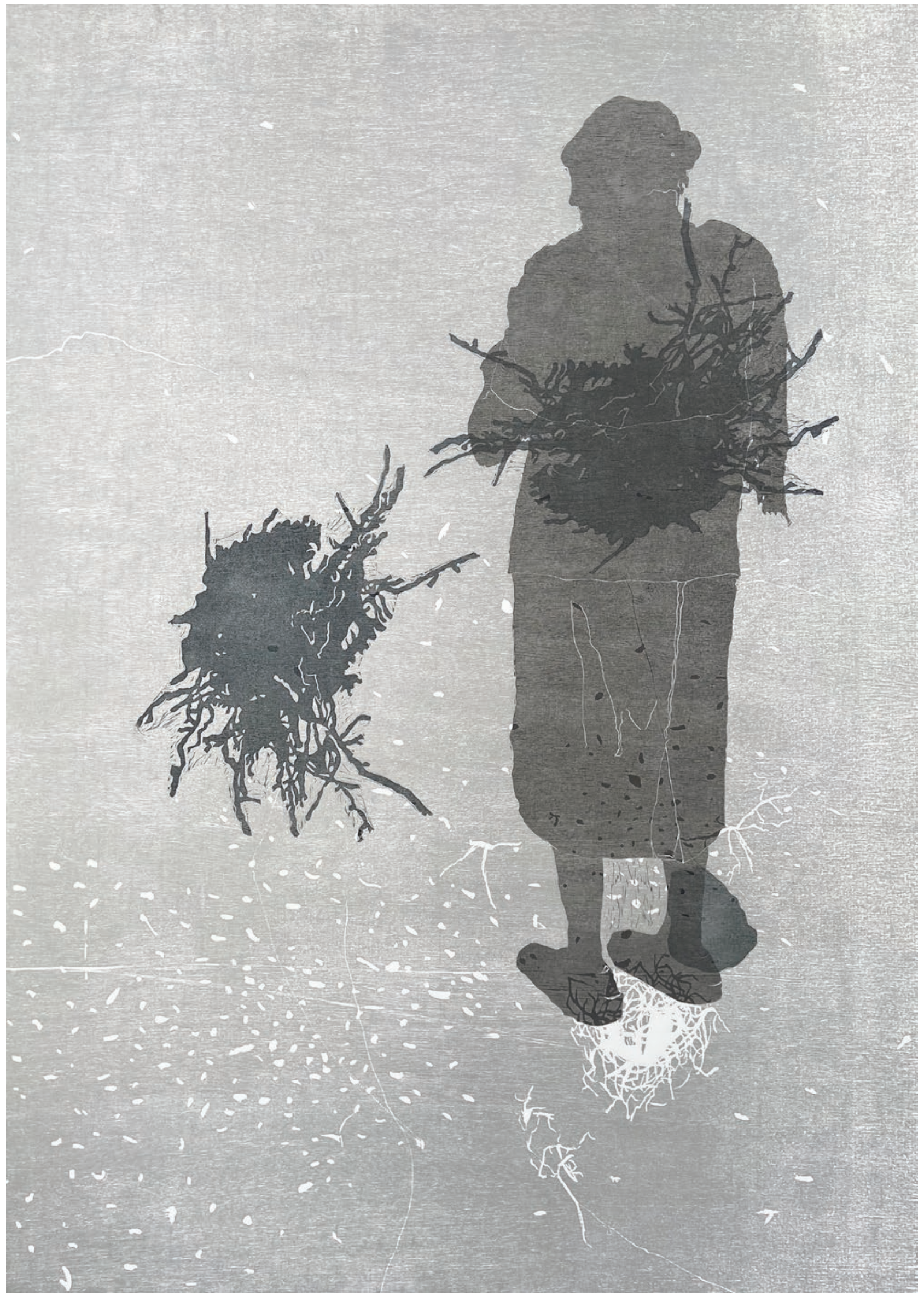




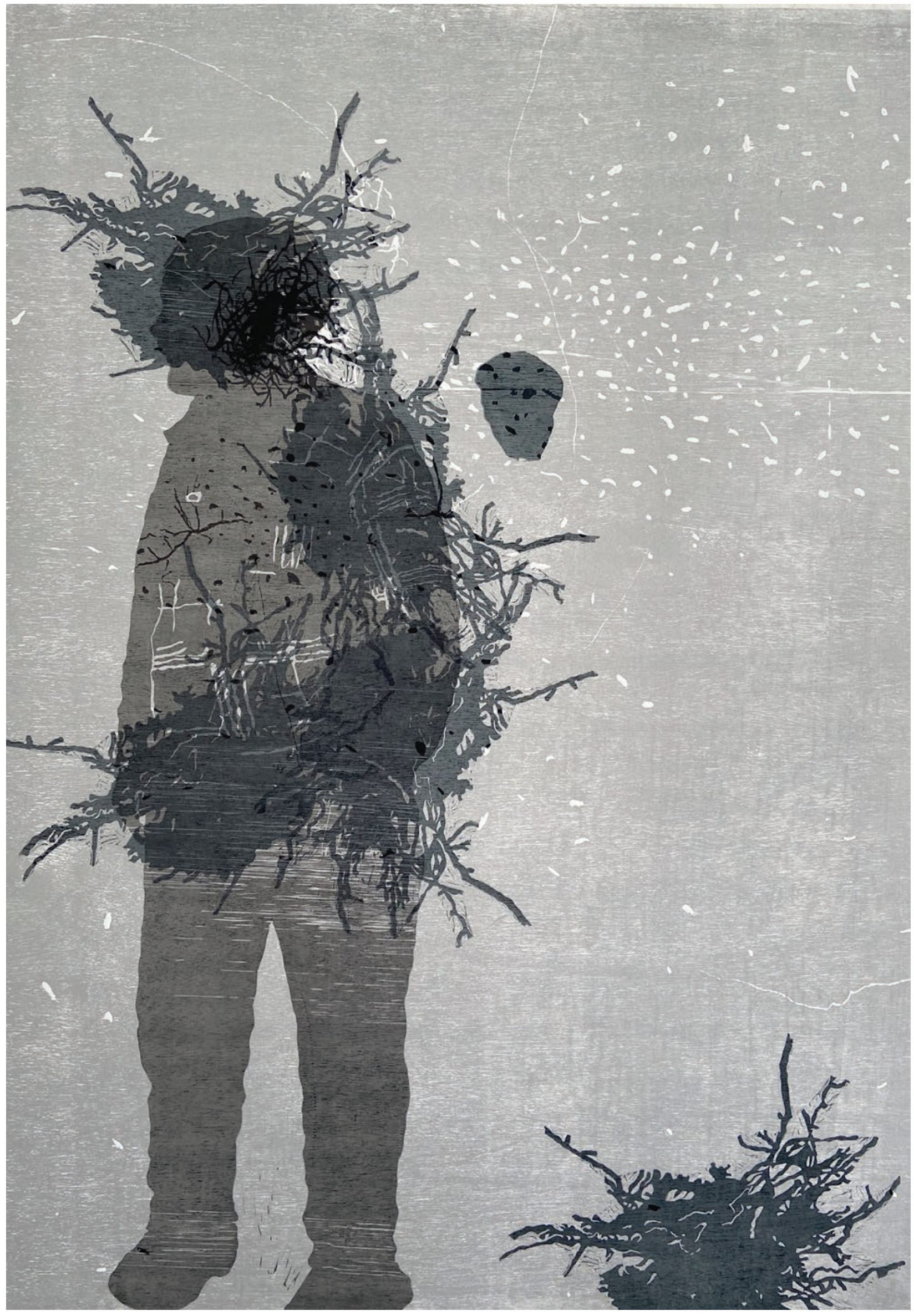




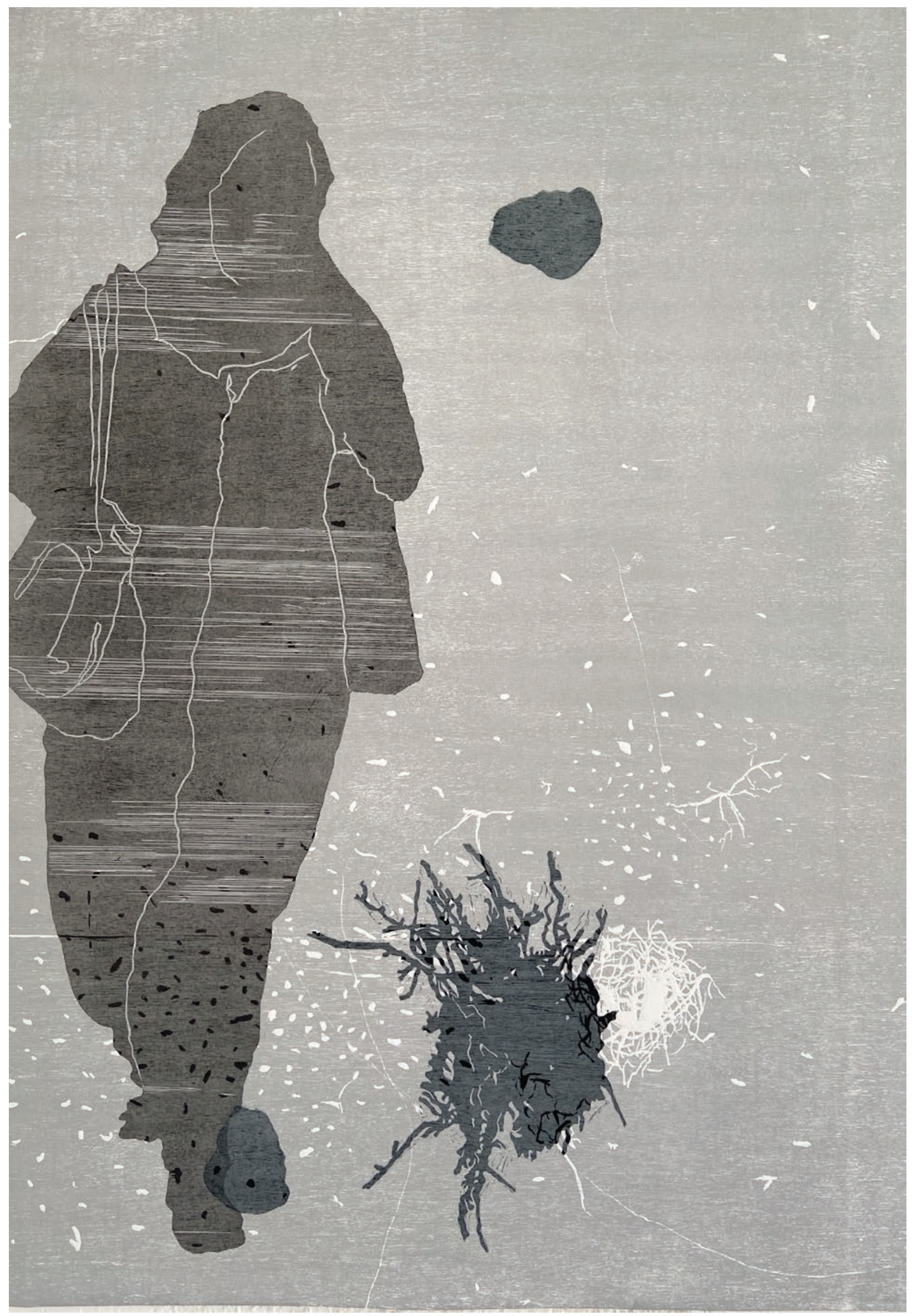




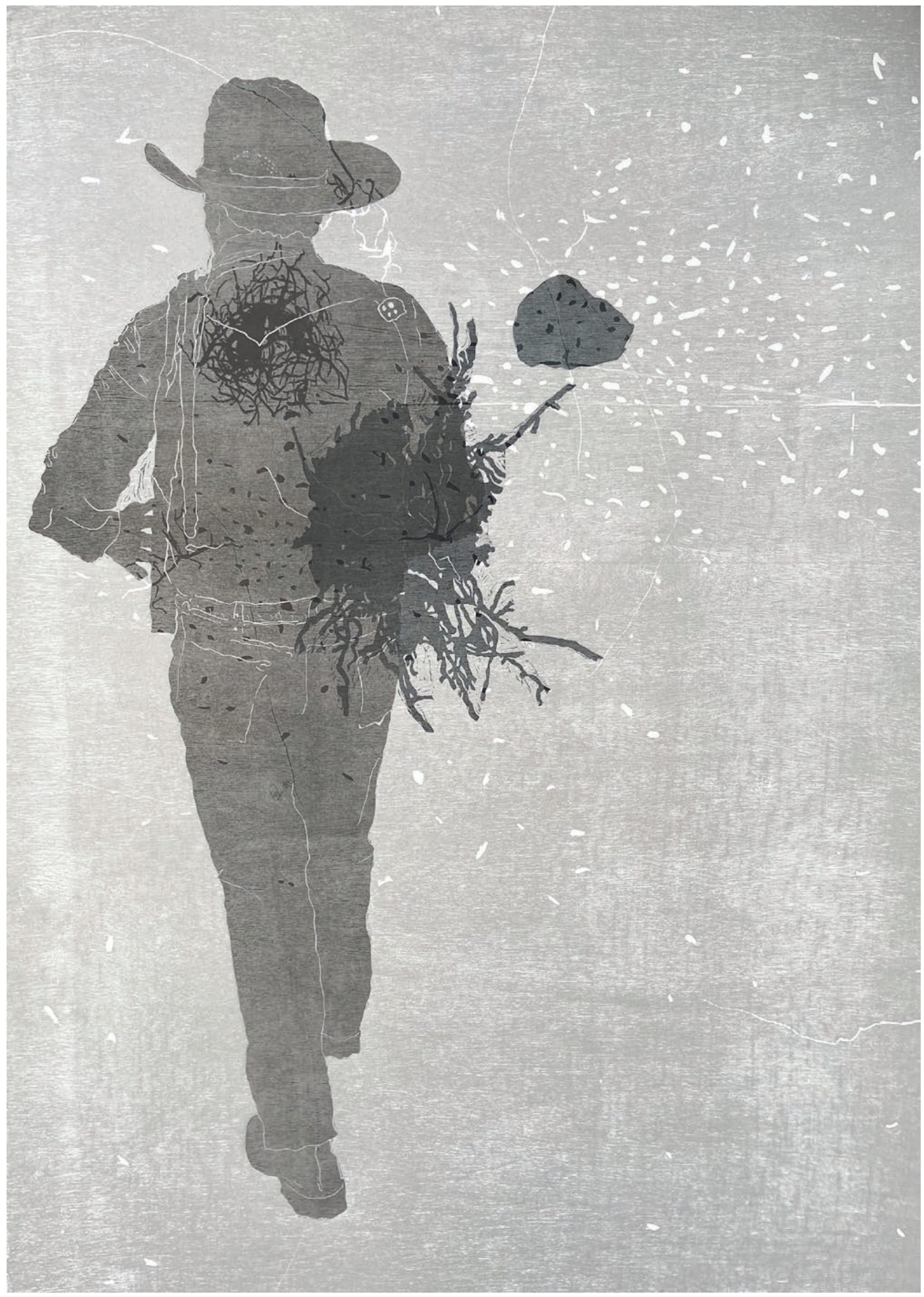


SEMBLANZA

ANA Rojas (Cuernavaca, México, 1979). Artista gráfica. Su obra se desarrolla en torno a la metáfora de la movilidad humana y su relación con el entorno. Mientras que en el Laboratorio de Arte Múltiple e Impresos -el cual fundó en 2015- indaga sobre las posibilidades del arte múltiple, con el fin de democratizar la obra de arte, dando forma a dicha investigación, al exponer, producir y editar la obra de numerosos artistas.

Licenciada en Artes por la Universidad Autónoma de Estado de Morelos. Especialista en grabado y estampa por la Fondazione Il Bisonte per lo Studio dell' Arte Gráfica en Florencia, Italia. Ha realizado alrededor de 40 exposiciones colectivas y 9 individuales, nacionales e internacionales, además de haber sido seleccionada en más de 10 certámenes y Bienales de artes gráficas. 